\title{
The creation of the first marine biological stations in North Russia
}

\author{
T. A. Ginetsinskaja \\ Department of Invertebrate Zoology, St. Petersburg University; Universitetskaya emb. 7/9, \\ St. Petersburg 199034, Russia
}

The natural resources of northern Russia remained almost unknown until the last decades of the 19th century. It was therefore not surprising that one of the paramount problems, as stated by the then newly-created St. Petersburg Society of Naturalists, was the investigation of the northern regions of the country and of the seas bordering them.

In the very first year of its existence (1868), the Society carried out an expedition with two zoologists (F. F. Iarzhinskii and V. E. Iversen), one geologist (A. A. Inostrantsev), and one botanist (A. Sokolov) for the investigation of the flora and fauna of the White Sea and Murmansk coast of the Arctic Ocean (Barents Sea), and the geological characteristics of this region. Information on the fauna of these regions was sparse, especially on lower animals, where it was almost nonexistent, apart from the rare reports and the small collection of invertebrates by the academician Karl von Baer.

The first expedition lasted several months. Various and abundant material (a well stocked herbarium, algae, a rich variety of both vertebrate and invertebrate animals) was collected on this expedition, and important geological investigations were carried out. After the second trip by zoologist F. F. Iarzhinskii in 1870, the investigations on the White Sea were interrupted for several years and not renewed until 1876 when the expedition of zoologists and botanists led by Prof. N. P. Vagner, the head of the "Zootomic Cabinet" in St. Petersburg University, left for that region. The Solovetski Islands were chosen as the centre of the expedition, and Prof. Vagner settled there in the inn of the famous Solovetski Monastery, sending his young colleagues on the voyages. The expedition worked for three summer seasons. By this time, Professor Vagner had fully realized the necessity and the importance of a permanent station for the serious investigation of marine fauna. The idea of a biological station on the coast of the White Sea was created; for this would be convenient not only for scientific investigations, but also for the marine zoological practical work of university students.

For Professor Vagner, the Solovetski Islands seemed to be the perfect place for such a station: the abundance of marine fauna, the long Solovetski Gulf with a lot of small bays, convenient for the collection of material, the neighbourhood of Solovetski Monastery - all of these seemed to be particularly advantageous - and he asked the Head of Solovetski Monastery, Archimandrit Meletii, to build the house for the biological station. Archimandrit, being a clever and active person, agreed to Vagner's proposition, because he hoped to receive from the station the assistance he needed to solve the practical aspects of some 
scientific problems; for example, the monastery was interested in the introduction of some fish species into the numerous lakes of Solovetski Islands; the collection of eider down had to be regulated by supporting the protection of the birds, i.e. both their nests and eggs. The biologists, working at the station, would be able to help in the resolution of all these problems. Professor Vagner and Archimandrit immediately became businesslike, and the latter, who was soon made an Honoured Member of the St. Petersburg Society of Naturalists, consented. Permission from the Sacred Synod was also received. In the summer of $1882, N$. P. Vagner had already worked on the premises of the newlyopened station, which had been built in the grounds of Solovetski Monastery.

During the 17 years of its existence, the Solovetski Station played a major role in the development of natural sciences, particularly zoology. More than 50 persons visited the station during this period, mainly students and scientific workers from St. Petersburg University. They succeeded in taking stock of the White Sea fauna, especially of the invertebrates, thereto almost unknown.

Among the numerous publications that were issued covering the results of the Station's activities and the work of preceding expeditions, was the excellent monograph by N. P. Vagner "The invertebrates of the White Sea" (1885), which included a collection of wonderful drawings by the author. Together with the faunistic data, Vagner presented in this monograph the results of his anatomical investigations, in particular the now wellknown data on the blood circulatory system of the pteropoda mollusc Clione limacina, and of some other White Sea molluscs, ascidians, etc.

The monograph by S. M. Herzenstein, describing in detail the White Sea malacofauna, and that of K. S. Merezhkovsky "Studies on protista animals of North Russia" (1877) were also of great importance. The publication of the latter was one of especial importance, for data on the unicellulars had been lacking in the Russian zoological literature of that period; and thus the monograph by Merezhkovsky became one of the first serious works in the field of protistology that was only just beginning and has today become a special and important field of zoology.

The work of F. F. Iarginsky, V. E. Iversen and D. D. Pedashenko formed the foundation for parasitological investigations, which were later developed further in Petersburg (Leningrad) University. The comparative-anatomical, histological and embryological investigations by Professor V. M. Schimkievitch were pioneers in their field. Apart from these, experimental work was carried out at the station that led to a better understanding of the complex life history of some parasite Crustacea (Lernaeocera, Dendrogaster), and to an evaluation of their position in the system (D. D. Pedashenko, 1898; N. M. Knipovich, 1890). Last but not least, it was the White Sea material that led to the formulation of two important theories, nowadays truisms, but at that time unprecedented and significant - i.e. the necessity of dividing the previous phyla Spongia and Coelenterata into two separate ones, set up by K. S. Merezhkovsky (1879), and the idea of the complexity of organisation and species diversity of the Protozoa, also formulated by this scientist.

The wide spectrum of investigations carried out at the station should also be mentioned; fauna and flora collections (particularly algae) were made; hydrologica] studies were carried out.

Finally, the vast geological studies by A. A. Inostrantsev need to be remembered, including those which, together with the faunistic data received during the investigation 
of the White and Baltic Seas, allowed the proposal of an important idea - now precisely defined - on the origin of White Sea fauna.

Meanwhile, the increasing popularity of Solovetski Biological Station, and the increasing number of those who wished to work there meant that the laboratory building became too small. Thus, the necessity arose of enlarging existing parts, or the building of new sections. However, after the death of Archimandrit Meletii, the situation of the Biological Station in the monastery became difficult. The new Archimandrit disapproved of the station entirely. The extension to the station was out of the question now. Archimandrit Ionikii sent a long letter to the Synod, in which he accused the co-workers of the Biological Station of breaking the monastery regulations, and in which he asked the Synod to remove the Biological Station from the monastery territory. Neither the activity of the President of the Society of Naturalists, A. N. Beketov, nor the intervention of the Grand Prince Alexander Mikhailovich, were able to help. In February 1899, the Synodal resolution "on the removal of the Biological Station from the territory of Solovetski Monastery" was proclaimed. In June of the same year, the Station's property was transported to Arkhangelsk.

The well-known Solovetski Biological Station of St. Petersburg University ceased to exist. It was succeeded by another institute - the Murmansk Station, which also played a major role in the study of nature in the northern realm.

The coast of the Barents Sea, with the newly-built port Alexandrovsk (now - Polarny) had been chosen as the site for the construction of the new marine station that was to succeed the Solovetski Station.

The organizer of this station was Konstantin Michailovich Derjugin - a person of abundant energy, a well-known hydrobiologist, professor at Petersburg University, and President of the Society of Naturalists.

Building of the new marine station began in 1899 and was finished in 1903. At the same time, the annual budget of the station was confirmed; the station received a sailing boat, and in 1908 a special research vessel - the schooner "Alexandr Kovalevsky" - was constructed. From this moment on, it became possible to carry out comprehensive studies of the Kola Gulf. The publication of the widely-known work by K. M. Derjugin "Kola Gulf fauna and the conditions of its existence" was one of the first important results produced by the new marine station. At the same time, collection of fishes and invertebrates of the Barents Sea for zoological museums and for the support of laboratory work on zoology in Russian universities and schools was organized.

For 25 years, from 1908 onwards, the German zoologist G. A. Kluge was the director of Murmansk Biological Station. During this period, the research station, though not large, became a well-equipped scientific institution with a marine aquarium, library, museum, ships and everything else necessary for marine investigations. Each year, about 30 persons worked at the research station, mainly zoologists from Petersburg and other Russian universities. Among them were many students who later on became famous representatives of Russian science, e.g. V. N. Beklemischev, who worked in the field of zoology, parasitology and comparative anatomy of the invertebrates; P. G. Swetlov, an embryologist; D. M. Fedotov, a zoologist, who studied the laws of evolution of invertebrates; B. N. Schvanaistch, an entomologist, the author of a fundamental manual; A. A. Polkanov, a well-known geologist and member of the Academy of Sciences; and many other specialists. 
The Murmansk Station worked intensively and successfully until the 1914-18 war, when significant difficulties arose. In August 1915, the work at Murmansk Station stopped because its buildings were temporarily occupied by the Naval Ministry. The Station suffered especially during the civil war. Nevertheless, after having been interrupted, scientific work was taken up again. The Station participated in the realization of the World Programme of complex investigation of Northern Seas, within the framework of which more than 20 voyages along the Kola meridian from $69^{\circ}$ up to $78^{\circ} \mathrm{N}$ were carried out in the period from 1921 to 1930 . During these voyages, biological, meteorological, hydrological and hydrochemical investigations were carried out. In 1928, the famous polar investigator Fridtjof Nansen visited the Station. Being acquainted with the work carried out there, he expressed his appreciation of its scientific significance, saying that even if the Station work was limited by longitudinal sections, this aspect alone would justify its existence.

In 1925, the status of the station was changed - it left the Society of Naturalists to become independent, but not for long. In 1929, Murmansk Station was connected with the Floating Marine Scientific Institute and, furthermore, became a branch of the State Oceanography Institute. Therefore, the main themes and focus of investigations changed. Hydrobiology, comparative physiology, anatomy, etc. became of secondary importance. Investigations in the field of ichthyology became the centre of interest now. This period did not last very long either. In 1933, the unexpected, now well-known, catastrophe began. The scientific staff of the station and its director G. A. Kluge were declared to be "vermin" - all the members of the staff were arrested, and the station was abolished.

However, the need for a biological station on the northern sea coast was so great that in 1939 a new Biological Station, also called "Murmansk", was opened on the Barents Sea. This station developed into an independent biological institute.

Acknowledgement. This manuscript was prepared and translated due to financial support from the St. Petersburg Society of Naturalists.

\section{LITERATURE CITED}

Derjugin, K. M., 1915. Kola Gulf fauna and the conditions of its existence. - Zap. imp. Akad. Nauk (Ser. 8, Fis. - mat. Otd.) 34, 1-929. (In Russian)

Herzenstein, S. M., 1885. The fauna of the Murmansk coast and the White Sea. - Trudy imp. Speterb. Obshch. Estest. 16(2), 635-814. (In Russian)

Inostrantsev, A. A., 1872. Geological investigations in the North of Russia. - Trudy imp. S-peterb. Obshch. Estest. 3, 165-339. (In Russian)

Iversen, V. E., 1870. A report on a journey to the coasts of the White Sea. - Trudy imp. S-peterb. Obshch. Estest, 1, 89-99. (In Russian)

Knipovitsch, N. M., 1891. Dendrogaster astericola nov. gen. et sp., eine neue Form aus der Gruppe Ascothoracidae. - Biol. Zbl. 10, 707-711.

Merezhkovski, K. S., 1877. Studies on the Protista animais of North Russia. - Trudy imp. S-peterb. Obshch. Estest. 8, 203-288. (In Russian)

Merezhkovski, K. S., 1879. The investigations on the Spongia of the White Sea. - Trudy imp. Speterb. Obshch. Estest. 10, 1-83. (In Russian)

Pedaschenko, D. D., 1898. Die Embryonalentwicklung und Metamorphose von Lernaea branchialis. - Trudȳ imp. S-peterb. Obshch. Estest. 26, 247-307. (In Russian) 
Schimkievitsch, V. M., 1889. Observations on the fauna of the White Sea. - Trudy imp. S-peterb. Obshch. Estest. 20(1), 1-93. (In Russian)

Vagner, N. P., 1885. The invertebrates of the White Sea. Stasjulevich, St. Petersburg, 171 pp. (In Russian)

Yarginski, F. F., 1870. Preliminary information on the results of the expedition of the Zoological Department to the White Sea. - Trudy imp. S-peterb. Obshch. Estest. 1, 80-88. (In Russian) 